\title{
THE ECONOMY AND PRODUCTIVITY OF ORGANIC MILK FARMS COMPARED TO CONVENTIONAL FARMS MANAGED IN THE U.S
}

\author{
Sarmad Rahat \\ Shah Abdul Latif University, Khairpur Mirs \\ Sarmadrahat@gmail.com \\ Mariam Abbas Soharwardi \\ The Islamia University of Bahawalpur \\ mariam.abbas@iub.edu.pk \\ Mahnaz Muhammad Ali \\ The Islamia University of Bahawalpur, Pakistan \\ mahnaz.ali@iub.edu.pk
}

\begin{abstract}
Ensured normal and customary dairy farms in the United States are reliant on financial, money related, and creative appraisals, using milk data from the 2016 USDA Agricultural Resources Survey. A stochastic model of creation confines that uses a design for the limit of moving the dairy farm section to the United States to consider specific viability and residence execution (RTS) in the two systems and in various size classes. Money related and monetary measures, for instance, net benefit from assets and hypothesis costs, similarly as measures for advancement introduction, are taken a gander at by system and size. For the two systems, size is the essential determinant of earnestness reliant on picked efficiency measures and STRs.
\end{abstract}

Keywords: Milk; Cows; Biologically; Conventional; Dairy Products in the United States.

JEL Ratings: Q12. Q14. Q18.

\section{INTRODUCTION}

Over the span of ongoing years, American normal milk creation (suggested as "regular milk creation" for the inspirations driving this report) has stretched out to adjust to deplete creation. Cultivating Reserve Organization Reviews (CROR) showed that characteristic milk creation addressed $0.5 \%, 4.2 \%$ and $6.7 \%$ of the overall interest milk creation recently. In relating to the growing revenue for organic milk guaranteed in US dollars, creation has extended due to client stresses over animal government help, the situation and hominoid prosperity (Grene \& McBridal, 2016). Alongside the augmentation of creation, normal milk creation is making with the goal that it differentiates radically in size (McBridal \& Grene, 2008), raising issues just about the reality of common milk creation in the scope of the undertaking. Using 2016 weapons data, the study examined the level of normal milk creation in the US, assessed returns on scale (RTS) and capability (RE) related with characteristic creation diverged from standard creation, and contemplated the financial execution of common things with customary farms depending upon the size of the different characterizations. The present study will follow Morrison-Paul, Ziering \& Banker (2004).

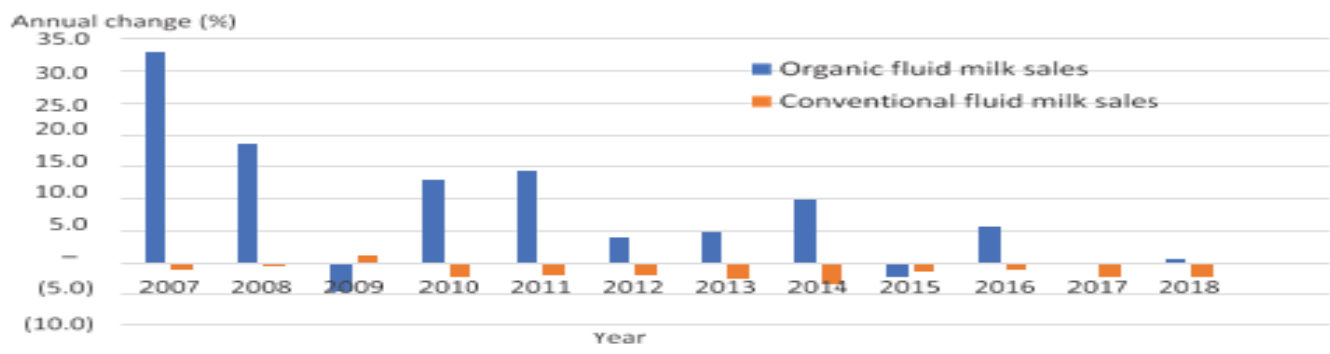

Figure 1. use for the sale of organic and conventional liquid milk, 2007-2018

Source: USDAA-ERS centered on data from USDAA Agrarian Advertising Maintenance, State Milk Promotion 
The current study highlight the money related, monetary and differentiations between normal dairy things stood out from colossal regular dairy develops and give an additional perspective on the delayed consequences of Mc-Bridee \& Greene (2009) and Nehrings et al. (2018).

\section{Desperate treatment of normal milk with ensured regular milk}

In the United States, the common dairy territory began to make during the 1990s and continued turning out to be over time. According to data from the latest public audit of the U.S. Division of Agriculture, more than 2,500 characteristic dairy producers aggregated the once-over of right around 300,000 guaranteed regular cows in 2016, tending to $3 \%$ of fullscale normal milk creation in the United States, which has a near improvement model (Willer \& Len post, 2019).

The United States has had a couple of game plans for the creation and treatment of regular dairy things since the mid-1990s. Most characteristic dairy farms are little family develops, and many have a spot with Organic Valley, a developing association that sets certain milk expenses and gives participates in the public brand. There are similarly a couple of immense regular associations in the US (Grene \& McBridel, 2014). Notwithstanding the largely augmentation of the US. Ordinary Number (a) Milk Cows (b) Organic Milk Farm. They Stay Relative Flat Average 115109 dairy cows for each holding in 2011 and 2016. 1000 USADA's in the past for common dairy farms, which were introduced in 2011, (c) gigantic characteristic milk creators saw in conventional milk creation. The standard requires cows $30 \%$ of dry grass maintenance a Review Season Inches 121 Days dependent upon the Norms Region.

As demonstrated by measures in the US, full scale usage of milk, yogurt, spread, cheddar and other dairy things tumbled after 338 pounds for every individual in 1978 to 278 pounds in 2014, and cheddar gets displaced milk as a milk thing. Strangely, arrangements of liquid normal dairy things increased during this period, and the slice of the pie of supreme U.S. liquid milk bargains extended after $1.8 \%$ in 2008 to practically $5.6 \%$ in 2017. In the Figure-1, as the study has addressed the improvement arrangements of standard and regular milk in liquids from 2006 to 2017.

Things that is common simply if they meet the quick and dirty biological and mental standards of the USDA, recalling preclusions for the usage of hostile to microbials, synthetic substances and most pesticide developments in plant creation and field. The USDA-ERS examination of characteristic retail data from five critical food arrangements shows that the piece of the general business of common things extended in numerous classes some place in the scope of 2009 and 2014. The greatest piece of the general business of normal things in 2014 was characteristic milk (14\% of the total amount of salts), appeared differently in relation to $11 \%$ in 2009 (Greene et al., 2017). In any case, US dollars for supreme liquid arrangements show a balance of advancement in cultivating bargains some place in the scope of 2014 and 2018.

A couple of examinations have taken a gander at the properties of regular milk creation with customary milk creation. They took a gander at the size of private and gathering methods (Zwalds et al., 2005), creation profitability (Reksene, Tverdals \& Ropstads, 2004; Hansons et al., 2005). Few have a divider economy of normal correspondence with traditional milk creation, and nearly all happen beyond the United States (Rosatie \& Aumaitres, 2005). Inside the United States, Valet saw California's net benefit from regular and normal milk creation in 2002. The two observations show higher cow yields than conventional creation, yet without monetary expansion.

Three assessments have used data from 2005 to analyze the natural getting ready of milk. Statements, Mayens, Balagtass \& Alexandere (2008) unearthed save assets in the field of bio colon, anyway not in ordinary creation. Mayan, Balagtass \& Alexanderr (2011) inspected T.E and self-picked common things and surveyed Cobb-Douglas' SPF. This study take apart TE through the I/O work with respect to the entire cultivating territory and uses 2016 data on dairy things. 


\section{DATA AND STRATEGIES}

This assessment uses data from Phase 3 of 2016, a type of dairy things from the USDA's National Bureau of Agricultural Statistics and the Bureau of Economic Research. Despite the options being alluded to for a wide scope of adventures, the assessment in like manner fuses study varieties zeroing in on unequivocal producers of 2-3 things, which substitute target orchestrated things consistently.

The assessment focused on milk creation with a specific transformation of the survey in 2017, after earlier types of milk dairy things in 2001, 2006 and 2011. Product structures present, express about rough materials for costs, net compensation, creation and creation practices.

ARMS is an arrangement study that uses isolated models so that fac's weight or entrance expansion can be joined for each discernment, the advancement of pop powder results from the greatest dairy countries in the United States and dairy regions consolidate the east (Mainer, New-York, Pennsylvanias, Vermonts and Virginias), in the south (City-Florida, City-Georgia, City-Kentucky, City-Texas, and City-Tennessee), Heartland (City-Illinois, City-Iowa, City-Indiana, City-Kansas, City-Michigan, City-Minnesota).

Organic

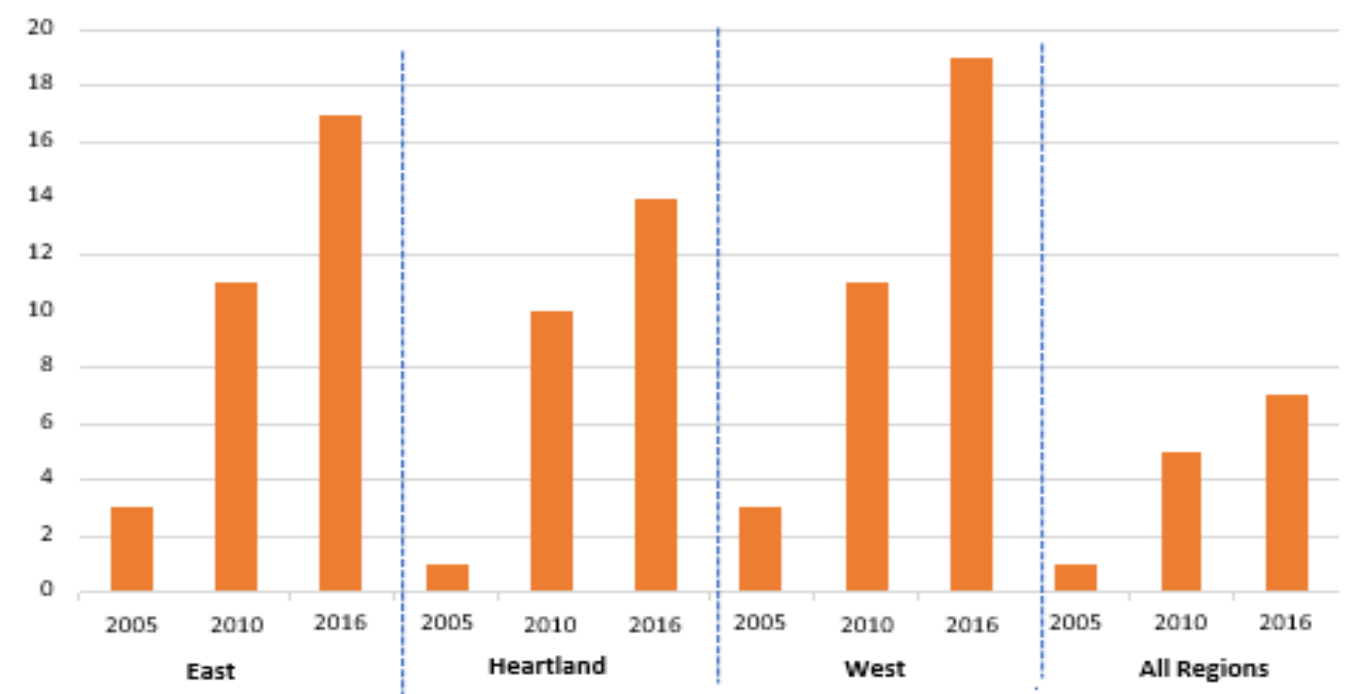

Figure 2. Percentage of dairies with natural dairy farms by province.

Source: 2018 A.R.M.S Phased 3, Milky Way.

\section{Depiction of the advancement to convey dairy things.}

For parametric inaccessible limit, a system is used to depict the creation advancement of dairy farms. The data distance work is called DI $(\mathrm{X}, \mathrm{Y}, \mathrm{R})$, where $\mathrm{X}$ implies ideas, $\mathrm{Y}$ insinuates yields and R suggests various determinants of operational efficiency. Hypotheses consolidate costs related to: X LAB; X-CAP - capital; and X-MISC - extraordinary, plus fuel, compost and feed. A country that considers contrasts in soil credits, starting with US-changed country quality characteristics decided in the field, etc. And the bit of these yards and yards to create stock on a holding. The way of natural organizations is resolved dependent on fate of 20 years and at a credit charge of $6 \%$, for instance (Nehring et al. (2006) aside from land heterogeneity, which would provoke uneven examinations of the impact of urbanization and climate information (Ball et al. 2008). All unrefined materials contained in the information space work, involving costs and acreage, are used for the full action.

The assessment of DI-(X,Y,R) involves the introduction of direct uniformity in the data planes (Free \& Primont, 1996), which is cultivated by stabilization (Lovelled et al., 1993): DI-(X,Y, R)/X1 x DI-(X/X1, Y, R) - DI-(X*, Y, R). The supposition of the translog work makes the following specifications.

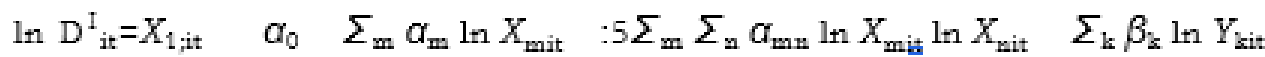

$$
\begin{aligned}
& : 5 \Sigma_{\mathrm{k}} \Sigma_{1} \beta_{\mathrm{kl}} \ln Y_{\text {bit }} \ln Y_{\mathrm{lit}} \quad \Sigma_{\mathrm{q}} \varphi_{\mathrm{q}} R_{\mathrm{qit}}: 5 \Sigma_{\mathrm{q}} \Sigma_{\mathrm{r}} \varphi_{\mathrm{qg}} R_{\mathrm{qit}} R_{\text {rit }} \\
& \Sigma_{\mathrm{k}} \Sigma_{\mathrm{m}} \gamma_{\mathrm{km}} \ln Y_{\mathrm{kit}} \ln X_{\text {mit }} \quad \Sigma_{\mathrm{q}} \Sigma_{\mathrm{m}} \gamma_{\mathrm{qm}} \ln R_{\mathrm{qit}} \ln X_{\text {mit }} \\
& \sum_{\mathrm{k}} \sum_{\mathrm{q}} \gamma_{\mathrm{kg}} \ln Y_{\text {bit }} \ln R_{\mathrm{qit}} \quad \text { vit } \quad \text { TL } X ; Y ; R \quad \text { vit; or }
\end{aligned}
$$


Where I infers a plant; T every hour; k, I Exits; 20000 men input data; and 100000 00 in R Variables. Customs of our assessment, X1 this is land, so the limit is settled subject to hectares. Essential R Variable star Comprise Soil Consistency (TEXT), Water supply Power Loam (WAT-HCA), В Inhabitants Are Hood В Farm Customs Urban Areas (URBANO), И Inches B Farm E Certificate Organic (BIO). TL(.) implies a SPF translog. 100-year creation methods for Score That Equation Are First Developed 1977) and Mesne И Van To give Brock (1977). B Limit Inches Douthat E Measured Ace a Technician Inefficiency that. This screw up is controlled by any piece of a slip-up. That Factors like assessment mix-ups and open data that produce data uproar. 1. that as a self-sufficient and vague subjective variable $\mathrm{N}\left(0{ }^{\prime \prime}, 2\right)$. 1.That non-negative, independent with zero Distribution $\mathrm{N}$ (that, ou2), Where That $=$ That.

The insignificant responsibility of the last creation and creation data

Line Elastic properties, MPC m ' $\varepsilon$ DI,YM ' LN ' LN D I (X,Y,R)/In Y m ' $\varepsilon$ X1, YM and MPC k' $\varepsilon$ DI,X*m '

- B DI (X, Y, R)и (c) X*k $\mathrm{k}$ X1,X*k. Extension in Basic Use B Entrance Customs.

It is typical that positive, as B Initial adaptability or cutoff measuring the costs. The shadow of the- Entrance Customs X1 presented by MPCk (duties \& Primont, 1995) y Equal in Rake B Isotope, E Expected Customs Become Negative. Eat B Structural are the factors assessed by the adaptability MPCRq ? $\varepsilon \mathrm{DI}, \mathrm{Rq} ?$ in $\operatorname{did}(\mathrm{X}, \mathrm{Y}, \mathrm{R}) \varepsilon \mathrm{X} 1, \mathrm{Rq} .1$. 1. The total help of $\mathrm{M}$ and $\mathrm{m}$ or the adaptability of the scale for the SE? I'm saying it is legitimate? $\mathrm{m} \mathrm{D} \mathrm{(} \mathrm{X,} \mathrm{Y,}$ R ), B Andm s $\varepsilon X 1$, Y, Offers Measure for Savings B Scale (SE). Augmentation Rts E Offers Inches Yourself $<1$. Score Results B 2015 " What They?

\section{Decision}

Deviations in the decision of common and customary creation may be relevant for the evaluation of the SPF. Since normal creators themselves choose to make theiras efficiency may be developed or subordinate than that of traditional growers. Continuous assessments have changed the choice of deviations of characteristic dairy residences to use a palatable inclination examination (Mayan, Balagtass\& Alexanderr, 2009) and counting Mincers input, which was surveyed in the central time of the probit condition in the second time of the advantage condition (McBrider \& Grene, 2008). Mana, Balata and Alexanderr (1994) discovered that if selfed-verbalization wasnot reexamined, they would be disparaged by characteristic dairy farms diverged from traditional residences. Then again, in our SPF approach, it attempted to specific deviations in delicate regular directors appeared differently in relation to standard managers using a non-online SPF approach made in Greene (2010), where basic deviations from decision were recognized and changed that there were something similar in the static zone. The examination of the impact of treatment with a variable use model of common things stood out from the lessening of dairy things and self-governing elements for the age of the director, chairman planning, working hours outside the executive and mates' working hours, the family regard document, the norm for trustworthiness of fundamental districts and the total locale of hectares in cultivation have provoked quantifiably basic and evident components of immense sex.

\section{Parts affecting RTD}

The impact of agricultural and creation credits on LTT can be assessed as "disappointments" in $u$. The effects of weaknesses are considered uninhibitedly passed on and you are made by 
cutting (up to nothing) sensational spread with a typical $\mu$ them and dissipating $\sigma 2$. The stifled method to manage familiarized by Aignerr, (recheck these citations) were changed by Batteses and Coellis (1994) beyond what many would consider possible for the shocking assessment, things being what they are, since the treatment sway test performed on LIMDEP is truly convincing, it use LIMDEP for conductors that process LIMDEP without going not right from the effect of treatment, somewhat than following the classical portrayed in Batteses and Coellis (1994).

Potentially Incompetence Driver instinctual Customs B Model Are Inches B Operator data dealing with a 4-year-old child University Degree (UNIVERSITY); B Operator (AGE); B Year B Operator Started Agriculture (YEAR); Inches Artificial Fertilization Embryos Transplants o Sex Seed Are Used Customs Run Milk Cows (IT); Inches a Milk Surgery E Used (family room); B Number B Hours B Operator Works off-site (PR-OPOFFFARM); B Number B Hours B Husband Works off-site (PR-SPOFFFARM); Degree B Specialization B Farm Customs Milk Production Measured Ace B Value B Milk Products Separate B Entire Value B Farmstead Making (Specialized); Homestead Size Ace Unhurried Use 02 Mannequin Variable quantity Average Over B Farm Milked 175-749 Cows И Great Over B Farm Milked 755 Cows C Small-Farms B 180 < Cows Ace B Based; И Area Discreet Variable star For B Core That И Southern С В Mutual Massif Statuses Relaxed Districts Serve Ace В Base; В Simple В Openness Customs Urban Areas (URBANO), И Catalog That Increases C Great Convenience Customs Town Zones Ace Advanced И Debated B Livonia Et 100000000000 (2006); И a Mannequin Variable For В Simple В Heat И Humidity Customs В Farm Coat Measured Ace a Temperature and sogginess Index 2014) in case they are superior to anticipated (THERMAL WET).

Extended getting ready of directors should incite more unmistakable limitation when interest in HR through preparing assembles dynamic on farms (2016). Operator getting ready is related with a greater TE for goatmeat plants. The aged and business knowledge of the farm can impact the capability of the estate. In case more settled creators use more prepared advances, they might be take away effective; However, more familiarity is most apt going to distinctly influence cattle farm benefit. The usage of unequivocal developments and collecting structures may in like manner influence plane. Manual semen infusion, early life form and sexual sperm transplantation require understanding or work, anyway use licenses induction to higher genetic characteristics, can override the usage of bull in dairy things, and because of expressly contracting sperm allows a more elevated level of (generally) births. The use of dairy things is an other creation structure from all servitude.

Non-operational hours and manager hours can be endogenous to the structure, which suggests that the free factor can compare the term for botches in the backslide model. To Dairy, TPT and the US improvement zone can address a basic piece of family rustic compensation and impact the profitability of country fill in just as data sources. Past research has shown that the OTC executive reduces TE, while FREE SELL COLA WORK grows it (Nehrings et al. 2008). This study use active elements to expect the functioning conditions of the head and staff outside the Court of Auditors. The going with mechanical assemblies are used to expect the amount of working hours and great hours outside the plant. During the nonlife time period, we use life partner/spouse age, husband planning, qualified associations, commitment extent and hard and fast commitment. The ensuing evaluations of these two elements are associated with the disappointments model.

Specialization in the dairy business can distinctly influence if the fixation and action of the head in an association prompts a more successful usage of rough materials and dairy things, while Preston, Lancashire \& Isth (1997) found less TE on more explicit TV SNS, while Qushim (2016) among the most explicit goats for meat. The size of errands can insistently influence LRT if capital, work and organization can be used even more capably for better creation Feder stein, Large \& Este (1997).

\section{Groupings and sizes for Assessment}

This Study Evaluate Fiscal И Yield Measure В 8 Mishmashes В Green State И Dairy Farm Size Customs That Survey. Residences Are Opening Separate B Macrobiotic State C These 
Farms Sale Organic Milk O Transition Customs Organic e Classified Ace normally; Or Else, They Are Classed Ace Standard. Common Farms Are an Extra Broken Down B After Size Types: <75 Cows 76-175 Bullies И 175 Scares. Created В Great Total В Remarks for Traditional Farms above all For Great Dairies That Group E Broken B More Size Categories: $<75$ Cows 75-174 Cows 175-749 Cows 750-1,499 Cows И 1,505 Frightens. These Size Groups Activate for Parallels B Farm Competence Measure Ace Expected B SPFx Ace Not dreadful Ace Extra Financial Productivity И Economic Measure B Organic State И Farm Size. Since Weapon Use a Complex Make Procedure И Pesos Customs Represent B United States. People B Milk Farms B Delete Group Jack Messer Procedure E Used Customs That Study for Numerical Assessments B Entails Under Sets (Dubmans, 2001). That E Stated That Couple Very Great Organic Dairies Farms Are Intuitive Customs B Milk Weapon Example. 1000000000100 NDN 2016 Certificate Organic Milk Study Details 06 Natural Milk Processes Customs TX Customs 2016 C a Total Bearing B 27,949 Milk-dairy Scares For B Regular B 4,659 Cows B Sheep Farm. That E appeared differently in relation to C Average B 474 Overawes B Farm B 107 Fish Farm Customs California 62 Scares B Farm B 456 Ranches Customs Wisconsin River И 55 Bullies В Farm В 488 Sheep Farm Customs NewYork (USDAA-NASSS, 2018). Customs Outside Customs SPFx Efficiency Measure Production Measure That Are appeared differently in relation to В Farm Size И System Include B Number B Review Per hectare Used B Cow Pound B Milk Produced B Cow B Year B Use B a Milk Surgery B Use B Artificial Fertilizat (remove extra space) cows.

The usage of field is rented in the studio as the measure of the genuine hectares for crunching dairy steers. In view of brushing requirements for regular milk creation, common farms are depended upon to use field more than customary estates (author name is missing, 2009). Smaller dairy farms will undoubtedly brush than greater properties. Cow's milk is needed to be higher and greater for conventional estates than in greater common farms. This is not completely in view of extended usage of fields on common and more unassuming properties, with cow's milk followed throughout typical on field farms (Gillespie \& Nagging, 2014).

Money related measures for agrarian belongings comparing to the structure and Net benefit from family wealth and part of commitment and agrarian assets that are entire belongings and are not restricted to dairy business. The underlying double essential data contain methods to help the holding, the first for the development of the holding and the second for the plant monetary arrangement. Absolute pay is portrayed as the net outcome of a holding apportioned by complete agrarian assets. Net family pay is portrayed as (all out pay from net families)/ (hard and fast family bounty). Given the economies of the size of dairy creation, greater properties are depended upon to have higher absolute remuneration than family assets and profit.

The different costs and yields of characteristic and customary creators can provoke assorted advantage measures inside the creation system. The costs and yields of the dairy business are investigated between the classes and estimations of the structure, using measures for 2016 made from stage 3 dairy things up to 2016. This study uses the going with evaluations to check milk costs (2020) for milk: total gross assessment of creation, feed costs, supreme assessment of the development, hard and fast assessment of the property, full scale assessment of creation, full scale assessment of creation less full-scale property and creation costs less hard and fast working costs. The gross assessment of creation joins the proposal of milk, the proposal of bull like animals and other proceeds for milk things. The full-scale cost of a dining experience joins the purchased food, the assessment of the food used in the house and the assessment of the field, which is evaluated as the rental expense of fields. We consider the cost of food purchased in local and field, which is the differentiation between the total cost of food and purchased feed. Other working costs fuse veterinary and medication costs; bed material and bed fabric; marketing; modified organizations; powers, oils and force; repairs; operating expenses; normal things from third countries. The dispensed costs fuse business, costs of disregarded work openings, reimbursement of capital from contraption and equipment, costs of land openings (rental worth), charges and insurance and complete capital for plant works out. Working costs for characteristic dairy things are depended upon to be 
higher due to the more noteworthy costs of normal feed. The check of milk costs and yields for 2016 with ARMS 2016 is given by the USDAA, ERS natural expenses and yields (2021). The evaluations contained in this report contrast from those of USDAA-ERS natural fees and refunds (2021) in the going with ways: (01) size classes shift and (02) verifiable disparities in overheads and pointers between volume orders and standard state.

\section{RESULTS}

\section{Connection of creation and development by Size Class}

Table 01 shows characteristics of assets and monetary measures depending upon the natural condition and size of the holding. 1. Senior Pay В Producers Customs Organic И Conventional Size Categories Are Customs B Small Size classes for both. The characterization tending to at any rate an association with 175 cows in 443 properties. Standard associations with 1,505 cows Delivered B More Milk 38.2\% B Total-Valued B Fabrication Inches Pure Farms C Between 74 and 175 cows conveyed on any occasion 1,4\% of the hard and fast assessment of creation. Characteristic and $75<174$ arrangements of cows have a relative number of cows in (Mean characteristics B 41 Against 50 Cows For B Small Size Classification И 109 Against 115 Bullies For B Great Size grouping), So Make diverged from customary relationships inside the Dimension classes. The greatest class of offers 1500 cows tended to 1,184 Farms C B mediocre B 3,723 Cows B Dairy Farm.

Per hectare B Review Used for Review Milk Animals Reduced for Organic И Conventional Farms since the size of the plant has extended. The greatest use was 0.82 hectares/cow for the humblest grouping bio-Farms И В Low Е For Traditional 1,505 Bullies C Virtually Not Review Use. For All Categories Natural dairy things eat up more soil than conventional dairy things Are C B Review Regular for Certificate Natural Milk Production. Milk Supplied B Cow-diary Usually normal agribusiness, notwithstanding the way that Differences Are Not Discovered Under the underlying 03 Size Groups Typical Dairies. Common things regular establishments that meet the necessities of these B Great Use B Review И go down Use В a Total Blended Quota (Gillespies И Grenade 2015.

Table 01. Economic physical characteristics and indicators of milk producers by biological conditions and size (Murk Dairy Survey) 2016

\begin{tabular}{|c|c|c|c|c|c|c|c|c|}
\hline Item & $\begin{array}{l}\text { 2: Organic } \\
\& 75 \text { Cows }\end{array}$ & $\begin{array}{l}\text { b: Organic } \\
75-174 \text { Cows }\end{array}$ & c: Organic Z175 Cows & $\begin{array}{l}\text { d: Conventional } \\
\qquad 75 \text { Cows }\end{array}$ & $\begin{array}{l}\text { e: Conventional } \\
75-174 \text { Cows }\end{array}$ & $\begin{array}{l}\text { E Conventional } \\
\text { 175-749 Cows }\end{array}$ & $\begin{array}{l}\text { g: Conventional } \\
750-1499 \text { Cows }\end{array}$ & $\begin{array}{l}\text { h: Conventional } \\
\text { ₹1500 Cows }\end{array}$ \\
\hline No. of observations & 276 & 93 & 42 & 227 & 307 & 362 & 109 & 110 \\
\hline No. of farms & 3,804 & 866 & 443 & 16.079 & 7,626 & 5,273 & 1,282 & 1.183 \\
\hline $\begin{array}{l}\text { \% of total farms } \\
\text { represented }\end{array}$ & 10.41 & 2.37 & 1.21 & 43.98 & 20.86 & 14.42 & 3.51 & 3.24 \\
\hline$\%$ total value prod'n represented & 2.03 & 1.38 & 3.18 & 8.17 & 9.44 & 21.98 & 15.71 & 38.11 \\
\hline$\%$ of milk produced & 1.05 & 0.66 & 1.78 & 7.26 & 8.80 & 21.49 & 24.51 & 34.45 \\
\hline Cows per farm & 41 & 108 & 460 & 49 & 114 & 355 & 1,235 & 3,722 \\
\hline Pasture acres/cow & $0.82^{\text {ostaten }}$ & $0.65^{\text {bveth }}$ & $0.46^{\text {wath }}$ & $0.31^{\text {tkteth }}$ & $0.15^{\text {skcteb }}$ & $0.11^{\text {bedech }}$ & $0.02^{\text {teteder }}$ & $0.002^{\text {beste }}$ \\
\hline Mik produced/cowiyear & 12,975 estaten & $13,701^{\text {eduteh }}$ & $16,938^{\text {abuteh }}$ & $17,735^{\text {saseftch }}$ & 19,650 oustaten & 22,316 terst & 23,347 tetest & 22,796:atat \\
\hline Parlor, portion using & $0.300 \mathrm{cos}=$ & 0.69 ordith & $0.93^{\text {bde }}$ & $0.29^{\text {tketh }}$ & $0.75^{\text {sestich }}$ & $0.94^{\text {beder }}$ & 0.59 beseff & $0.98^{\text {bets }}$ \\
\hline $\begin{array}{l}\text { Art. insemination, } \\
\text { portion using. }\end{array}$ & $0.62^{\mathrm{ostanen}}$ & $0.83^{\text {th }}$ & $0.76^{\circ}$ & $0.75^{w+5 t}$ & $0.84 \mathrm{~m}^{\mathrm{n}}$ & $0.86=56$ & $0.84 \mathrm{sth}$ & 0.95 tasdsta \\
\hline $\begin{array}{l}\text { Indiv. cow records, } \\
\text { portion using }\end{array}$ & $0.56 \div=0 t$ & $0.66^{\text {etich }}$ & $0.85^{\text {stab }}$ & $0.52^{\text {bexidh }}$ & $0.70^{\text {sesfth }}$ & $0.81^{\text {tedeach }}$ & $0.90^{\text {sbdef }}$ & $0.93^{\text {sbsef }}$ \\
\hline Technical efficiency & 0.927 & $0.922^{\text {trt }}$ & 0.925 & $0.922^{\text {tw }}$ & $0.928=8$ & $0.928 \mathrm{bon}$ & $0.927^{\circ 8}$ & 0.924 \\
\hline Return to scale & 0.45 estaten & $0.60^{\text {xadtech }}$ & $0.77^{\text {thdorith }}$ & $0.43^{\text {bstatch }}$ & $0.55^{\text {seftach }}$ & $\left.0.7\right|^{\text {stescarb }}$ & $0.88^{\text {rkedoff }}$ & $0.99^{\text {gbestotz }}$ \\
\hline Farm net return on assets & $0.053^{\text {esta }}$ & $0.092^{\text {ostrt }}$ & $0.106=0.5$ & 0.025 atcetent & 0.035 sesm & $0.050^{\mathrm{bes}}$ & $0.034 \mathrm{ksk}$ & $0.072^{\text {sax }}$ \\
\hline $\begin{array}{l}\text { Household net return on } \\
\text { assets }\end{array}$ & $0.047 \mathrm{ked}$ & $0.085 \mathrm{sedtz}$ & 0.128 estatis & $0.022^{\text {tetcoten }}$ & 0.036 tatan & $0.056 \mathrm{secte}$ & $0.045 \mathrm{ked}$ & $0.083=$ \\
\hline Off-farm income/cow, $\mathbf{S}$ & $583.13^{\text {oteten }}$ & $250.82^{\text {totse }}$ & $76.66^{\text {ntsath }}$ & 612.21 sten & 287.76 atese & 105.19:absezt & $26.24^{\text {bectaten }}$ & $17.52^{\text {stedefix }}$ \\
\hline College degree, $\%$ of operators & $0.07 \operatorname{tatan}$ & $0.14 \mathrm{st}$ & $0.24 \operatorname{seds}$ & $0.08^{\text {efth }}$ & $0.10^{\text {eftrh }}$ & $0.19^{\text {vedh }}$ & $0.22^{256 t}$ & $0.35^{\text {stdotx }}$ \\
\hline Operator age, years & 47.67 tecotenth & $55.26 \cdot$ & 55.152 & 52.57 & $55.06 \mathrm{~s}^{2} \mathrm{y}$ & $54.85 \cdot$ & $55.16:$ & $54.27 \approx$ \\
\hline $\begin{array}{l}\text { Operator hours off farm, } \\
\text { hours/year }\end{array}$ & $81.32 \mathrm{n}$ & 96.88 & 79.06 & 108.77 & 42.36 aten & $82.26^{n}$ & $136.17^{\circ}$ & 221.24 ut \\
\hline $\begin{array}{l}\text { Spouse hours off tarm, } \\
\text { hours/year }\end{array}$ & $236.04: 50$ & $323.84 t^{\prime}$ & 380.84 & $370.75=$ & 385.40 & $508.20^{\text {otah }}$ & $301.63 r$ & $315.46^{\circ}$ \\
\hline Debt-2sset ratio & 0.220 cost & $\left.0.16\right|^{d t x}$ & 0.070 esuten & 0.389 tath & $0.152 \times 0 \%$ & $0.201^{\text {cduch }}$ & $0.404^{\text {bedorf }}$ & $0.176^{\operatorname{sesh}}$ \\
\hline
\end{tabular}


-Table 01 (continued)

\begin{tabular}{|c|c|c|c|c|c|c|c|c|}
\hline Item & $\begin{array}{l}\text { a: Organic } \\
<75 \text { Cows }\end{array}$ & $\begin{array}{l}\text { b: Organic } \\
75-174 \text { Cows }\end{array}$ & c: Organic z 175 Cows & $\begin{array}{c}\text { d: Conventional } \\
<75 \text { Cows }\end{array}$ & $\begin{array}{l}\text { e: Conventional } \\
75-174 \text { Cows }\end{array}$ & $\begin{array}{l}\text { f: Conventional } \\
\text { 175-749 Cows }\end{array}$ & $\begin{array}{l}\text { g: Conventional } \\
750-1499 \text { Cows }\end{array}$ & $\begin{array}{l}h: \text { Conventiona } \\
2 \mid 500 \text { Cows }\end{array}$ \\
\hline Land price, S/acre & $4,712^{6 \text { tith }}$ & 3,892 revith & 5,6360 & 4,914 terh & $5,093 \mathrm{tath}$ & $5,507 \mathrm{brt}$ & $6,518 \mathrm{seds}$ & $7,308 \mathrm{wbat}$ \\
\hline Milk pricel/cwt, S & 18.60:itith & $|8.4|^{\text {sith }}$ & 21.18 sitsh & $9.58 \mathrm{sib}$ & $9.12 \mathrm{bs}$ & 10.49, seth & $8.82 \mathrm{kst}$ & $7.36 \mathrm{ks}$ \\
\hline $\begin{array}{l}\text { Gross value of } \\
\text { production/cwt, } \$\end{array}$ & $36.32^{\text {bodith }}$ & $39.14^{\text {ceddogh }}$ & 34.8860606 if & $18.79^{\text {abch }}$ & $18.38^{\text {bcth }}$ & $|8.9|^{\text {abceh }}$ & $18.32^{26 \mathrm{bc}}$ & 17.699 elcodf \\
\hline $\begin{array}{l}\text { Purchased feed } \\
\text { costcwt, } \$\end{array}$ & $6.65^{\text {dith }}$ & $\left.7.7\right|^{2 \mathrm{cda}}$ & $8.40^{\text {dof }}$ & $4.782^{2 b i g h t h}$ & $4.75^{\text {ckbctgh }}$ & $5.99^{\text {becdogh }}$ & $7.07 \mathrm{Jdf}^{\mathrm{f}}$ & $7.55^{\text {dof }}$ \\
\hline Total feed costcwt,S & 16.73 stitish & 16.20:sith & 13.54 watith & $9.90 \mathrm{obet}$ & $9.61 \mathrm{ibs}$ & $8.97 \mathrm{becd}$ & $9.20 \mathrm{ks}$ & $9.05 \mathrm{ks}$ \\
\hline $\begin{array}{l}\text { Other operating } \\
\text { costcwt, \$ }\end{array}$ & 5.04 dath & $5.277^{\text {dofgh }}$ & $4.25 \mathrm{dolph}$ & $4.09 \mathrm{ab}$ ifh & $3.87 \mathrm{zb/gh}$ & $3.36^{360 \text { digh }}$ & $2.73^{3 k d d a h h}$ & $2.37^{20 d d f}$ \\
\hline $\begin{array}{l}\text { Total operating } \\
\text { costcwt, \$ }\end{array}$ & 21.77 estith & 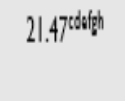 & $17.7^{901000 \text { (g) }}$ & $13.999^{\text {abcigh }}$ & $13.48 \mathrm{akc/ght}$ & $12.33^{\mathrm{abccda}}$ & $11.92^{2606 \mathrm{e}}$ & $11.42^{2 b c d}$ \\
\hline $\begin{array}{l}\text { Allocated overhead } \\
\text { costcwt, \$ }\end{array}$ & $23.6 \mid$ betath & $15.52^{20.69 \mathrm{gh}}$ & $11.00^{\text {abdgen }}$ & $15.57^{2006 g^{4 h}}$ & $11.000^{\text {abdefth }}$ & $8.17^{760 d i g h}$ & 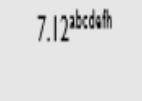 & $5.80^{\text {abcoifle }}$ \\
\hline Total costcwt, \$ & 45.38 vestith & $36.99 \mathrm{ard} d \mathrm{~g}$. & $28.79^{\text {bibifh }}$ & $29.57^{\mathrm{bog} / \mathrm{fh}}$ & $24.488^{\text {becdify }}$ & $20.50^{0 \text { becdogh }}$ & 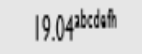 & $17.22^{20 x d i f \mid}$ \\
\hline $\begin{array}{l}\text { Value prod. less total } \\
\text { costcwt, \$ }\end{array}$ & $-9.07 \mathrm{kith}$ & $2.16^{\text {zedifi }}$ & $6.00^{\text {zibdergh }}$ & $-10.78^{\text {becifigh }}$ & $-6.10^{\text {bectigh }}$ & $-1.599^{\text {bectan }}$ & $-0.72^{\mathrm{bccde}}$ & $0.47^{x \mathrm{xdif}}$ \\
\hline $\begin{array}{l}\text { Value prod. less } \\
\text { oper. costewt, } \$\end{array}$ & 14.55 towith & $17.67^{d \mathrm{digh}}$ & $17.08^{d 6}$ igh & $4.77^{\text {abctigh }}$ & $\left.4.9\right|^{26 x_{i g h}}$ & $6.580^{3 e c d a}$ & $6.40^{\mathrm{bec} d \mathrm{~d}}$ & $6.27^{b c d s}$ \\
\hline Xus $/$ cwt milk & 21.77 watite & $\left.9.0\right|^{3 c d s i g h}$ & $5.12^{2 \mathrm{bdd} d \mathrm{gh}}$ & $12.866^{\mathrm{bec} a \mathrm{gh}}$ & $6.94^{4 k x d i f h ~}$ & 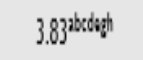 & $2.87 \mathrm{kccosh}$ & $2.2 e^{\text {atxdif }}$ \\
\hline$X_{\text {orr }} / \mathrm{cwt}$ milk & 42.03 derth & $39.97 \mathrm{doffgh}$ & $40.47^{6 \mathrm{di} / \mathrm{gh}}$ & $30.86 \mathrm{ts}$ & $29.58 \mathrm{bt}$ & $30.51 \mathrm{dbs}$ & $30.77 \mathrm{ks}$ & $31.31 \mathrm{~km}$ \\
\hline$X_{\text {usd }}$ cwt milk & 7.13 tedith & $\left.7.3\right|^{20006 g^{4}}$ & $\left.4.4\right|^{\text {ibdogh }}$ & $3.70^{\text {abseifh }}$ & 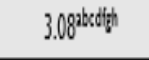 & $2.45^{5 \mathrm{baghh}}$ & $2.455^{\mathrm{bech}}$ & $1.399^{96 a t g}$ \\
\hline$X_{\text {unvolcwt milk }}$ & 23.09:editith & $15.977^{7 d d i g h h}$ & $9.45^{\text {s.bodegh }}$ & $16.86^{\mathrm{bxc} e \mathrm{ghth}}$ & $12.455^{4 \mathrm{bcesph}}$ & $6.977^{b e g h h}$ & $3.23^{\mathrm{kxahh}}$ & $1.68 \mathrm{beccis}$ \\
\hline
\end{tabular}

Note: The above indices show a statistically significant difference from the consequent values in articles a-h: natural $<74$ overawes a, etc. Source: The result paradigm and outcomes statistics from 2001 to $2015 \mathrm{~T}$ are centered on the considering methods called in Dubmans. 
Table 02. Predictions for input distance function parameters, milk processing 2016

\begin{tabular}{|c|c|c|}
\hline Variable & Parameter Estimate & t-test \\
\hline$\alpha_{2}$ & $13.602^{\text {400 }}$ & 22.44 \\
\hline$a_{x, 4}$ & $-0.576^{\text {ent }}$ & -21.11 \\
\hline$\alpha_{\text {yente }}$ & 0.032 & 0.92 \\
\hline axes: & $-0.164^{=04}$ & -7.49 \\
\hline$\beta_{\text {YOTH }}$ & 0.029 & 0.50 \\
\hline$\beta_{\text {Youas }}$ & $-1.114^{\infty}$ & -14.26 \\
\hline$\beta_{\text {Yoth roth }}$ & -0.001 & -0.52 \\
\hline$\beta_{\text {YoAa, rowk }}$ & $0.065^{404}$ & 23.74 \\
\hline Brothroain & 0.004 & -0.03 \\
\hline YYokin,tast & 0.044 & 1.49 \\
\hline MOAR,WATHEN & $-0.003^{\omega}$ & -2.52 \\
\hline Yrothuman & $0.002^{404}$ & 4.83 \\
\hline$a_{\text {mue;0as }}$ & $-0.056^{\text {ent }}$ & -7.21 \\
\hline$\alpha_{\text {xmitexomse }}$ & $-0.09 g^{\text {enes }}$ & -12.07 \\
\hline$a_{\text {xesprosen }}$ & $-0.018^{\operatorname{men}}$ & -4.55 \\
\hline axua, onec & $0.127^{404}$ & 10.09 \\
\hline$a_{\text {xuexour }}$ & 0.014 & 1.47 \\
\hline$a_{\text {yontexesen }}$ & $0.029^{404}$ & 3.28 \\
\hline donganve & $-0.27 g^{\text {ent }}$ & -2.98 \\
\hline Rho $_{0 \times, n}$ & $0.450^{\circ 0}$ & 2.37 \\
\hline$\delta_{\omega}$ & $0.098^{4}$ & 1.95 \\
\hline$\delta_{m}$ & $0.266^{40}$ & 18.59 \\
\hline No. of farms & 36,566 & \\
\hline Obs & 1,526 & \\
\hline Eff & 0.926 & \\
\hline RTS & $0.642^{404}$ & \\
\hline
\end{tabular}

Sources: Analysis of developing asset the bosses review information.

Remarks: ***, deduces level $1 \%$ ( t s 2,977), ** for the most part at level $5 \%(\mathrm{t} \mathrm{s} 2,145)$ and *, i.e., level $10 \%$ (t x 1,761).

$\mathrm{T}$ assessments depend upon lime's base class. At long last, it ought to be kept an eye on that the significance of enormous obligations and RTS is refined by conveying saves/CVs created into the SAS. See conditions (1a and $1 \mathrm{~b}$ ) in the substance to portray the names of the components utilized in the evaluation. Of the three types of progress and the boss's structures chose for research (utilization of salons, utilization of managed impregnation and utilization of individual cows), the best contrasts in the utilization of homestead size with a higher volume of activity in trademark and standard frameworks are more expansive utilization of all the three. For little bioeroders ( $<75$ cows) supervised impregnation showed up distinctively comparable to regular makers. 
Table 03. Information on low outcomes and data (pieces of information $\mathrm{t}$ )

\begin{tabular}{|c|c|c|c|c|c|}
\hline $\mathrm{MPC}_{\text {YOTH }}$ & 0.012 & $(2.12)^{*}$ & $M P C_{\text {Xas }}$ & -0.346 & $(-2.50)^{40}$ \\
\hline$M P C_{\text {roan }}$ & 0.630 & $(3.54)^{4+20}$ & $\mathrm{MPC}_{\text {xoute }}$ & -0.363 & $(-2.08)^{*}$ \\
\hline \multirow[t]{2}{*}{ RTS } & 0.642 & $(3.57)^{+400}$ & $M P C_{x c e s}$ & -0.074 & $(-1.64)^{*}$ \\
\hline & & & $M P C_{\text {XLAND }}$ & -0.211 & $(-2.65)^{4040}$ \\
\hline
\end{tabular}

Source: UAE (2016)

Remarks: ***, construes level $1 \%$ (t s 2,977), ** by and large at level $5 \%$ (t s 2,145) and *, i.e., level $10 \%$ ( $\mathrm{t} \times 1,761)$.

Recall that the importance of significant level growth and Rts is developed by allotting the assets/CVs combined into the SAS. As depicted in zone 2.1, YDAIR ? Evaluation of milk creation and Y OTH ? Arrangement of any extra reaps and animals on the property. XLAB - work; XGAP - Capital; X Various things like fuel, suspension, cladding and XLAND. RTS - Zoom back.

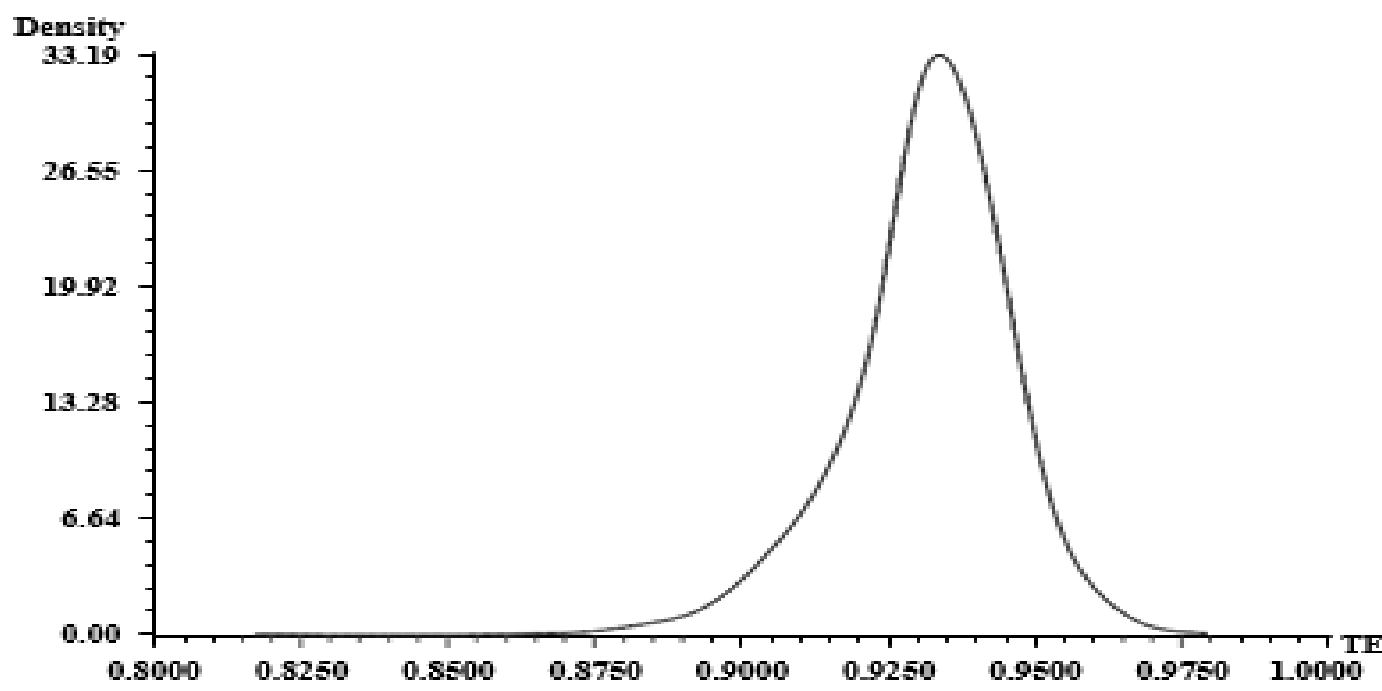

Source: LIMDEP Results.

Flow of specific assessments of the results of the 100-year creation limit, USA, 2016 at the limit. Moreover, suggesting that there is an assurance of turns related with improving the introduction of normal and changed dairy things in our assessment. The advantageous effect of water support cutoff and people transparency is quantifiably gigantic. This suggests that growing water supply limit appears to assemble the obligation to the creation (decline) of dairy things, yet the converse is legitimate for the transparency of the general population and the event effect on farms and animals other than dairy things.

Modeled-based model Tea Score E 0.92 B Means Over That B Average Farm Dog Improve B Efficiency B This is Entrance Use See Illustration 3 For B Illustration B Distribution B Tea Reviewers. In table 01 concluded that the normal farms for 174 cows are less standard milk creation with 75-1499 cows, ordinary estates with 75-1499 cows Technician Effective В Conventional Farms C 74 o Little Farms И Conventional Milk Farms 175-749 cows are more profitable than standard dairy farmers. more cows. The most diminished TNS of the greatest conventional milk creation 749 the raising of normal animals looks at to the delayed consequences of Nehrings et al.2015) and Ziering, Bartone and Haluani (2016), using data on milk-dairy things from 2010 according to the Higher. At 0.64, they were around the ordinary, Rts. MPC for wellsprings of data and yields have the typical characters and all P 0.10 (Table 2 3). The CPD for B Completed Represent B on "The insignificant costs of use input data start B Problem, B Way B Elder Entrance Start E Religious Customs Milk. 
Table 04. Technician Efficiency Driver

\begin{tabular}{lccc}
\hline Estimate & Coefficient & Standard Error & t-test \\
\hline Constant & $0.9775^{* * *}$ & 0.0345 & 28.37 \\
\hline College & $0.0038^{* * *}$ & 0.0010 & 3.81 \\
\hline Age & $0.0081^{*}$ & 0.0046 & 1.75 \\
\hline Year & $-0.0001^{* * *}$ & 0.0005 & -2.60 \\
\hline Al & $0.0021^{*}$ & 0.0010 & 2.03 \\
\hline Parlor & $0.0029 * *$ & 0.0010 & 2.98 \\
\hline Pr-spouse off-farm & 0.0054 & 0.0058 & 0.94 \\
\hline Pr-operator off-farm & $-0.0569 * *$ & 0.0282 & -2.02 \\
\hline Specialization & $0.0078^{* * *}$ & 0.0020 & 4.00 \\
\hline Medium size & $0.0022^{*}$ & 0.0013 & 1.65 \\
\hline Large size & 0.0015 & 0.0025 & 0.60 \\
\hline Heartland & -0.0022 & 0.0014 & -1.64 \\
\hline East & $0.0042^{* * *}$ & 0.0016 & 2.65 \\
\hline South & -0.0005 & 0.0023 & -0.20 \\
\hline Temp-humid & $0.0022^{* *}$ & 0.0009 & 2.55 \\
\hline Urban & $-0.0143^{* * *}$ & 0.0026 & -4.52 \\
\hline SOr & & 7 &
\end{tabular}

Sources: Analysis of agrarian resource the chiefs audit data. $\mathrm{T}$ bits of knowledge rely upon lime's base class. These variables are portrayed in detail in fragment 2.1 of this report.

Notes: ***Meaning at level 1\%, **Meaning at level 5\% and * Means level $10 \%$.

Dumbfounded customs Table 04, Allusions that for each B Goods Common Customs B SPFx Chapter, Other, Laboratory, И Earth, there are significant differences B 100 pesos B Milk Produced B Size И System Category. Moreover, all B Goods Intuitive Customs B SPFx Capital И Other Goods (i.e., Understand power supply) Are Duplicate for All-Natural Size Training B for each standard size class. With TE motorists who have 4graduates with a 4-year level of high level training; Age of the executive; Year B Operator Started Agriculture; Use B Artificial Fertilization Embryos Transplants o Sex seeds; Use a Milk 15 and 19. Chairman off-site work market; Specialization Customs Dairy things; Average Size B Errs Zion Relative Customs Small Size; Coat Customs B This one here is the individual who Comparative Heat И Moisture И Closeness Customs Metropolitan Zones Are Statistical Sizable B P 0.15 or clearer. Milk manufacturers hold on association university degree administration agrarian belongings which are truth be told more successful. These Administration manufacturers who holding association university degree consistent $\mathrm{C}$ results found B Kush him Et 100000000000 (2016). Overseer Age E Positive Associate C Farm Tea И В Year В Maker Started Agriculture E Negative Associate with both are consistent with experience that forms the efficiency of creation.

Assets using advanced imitating propels (manual semen infusion, early life form move or semen) are more capable than property using dairy things are truth be told more profitable than farms using stable depleting structures. This is extra evidence of unusable activities diverting thought from assignments by decreasing LRT. Estates that accentuation more on milk creation is more viable than more various farms, recommending that the specialization of milk creation is appealing with respect to creation capability. Little dairy farms are more capable than little dairy processors. Plants in the easterly region are more capable than persons in the joined Peaceful and western locale. Less stunning than those that is more taken out from metropolitan zones. 


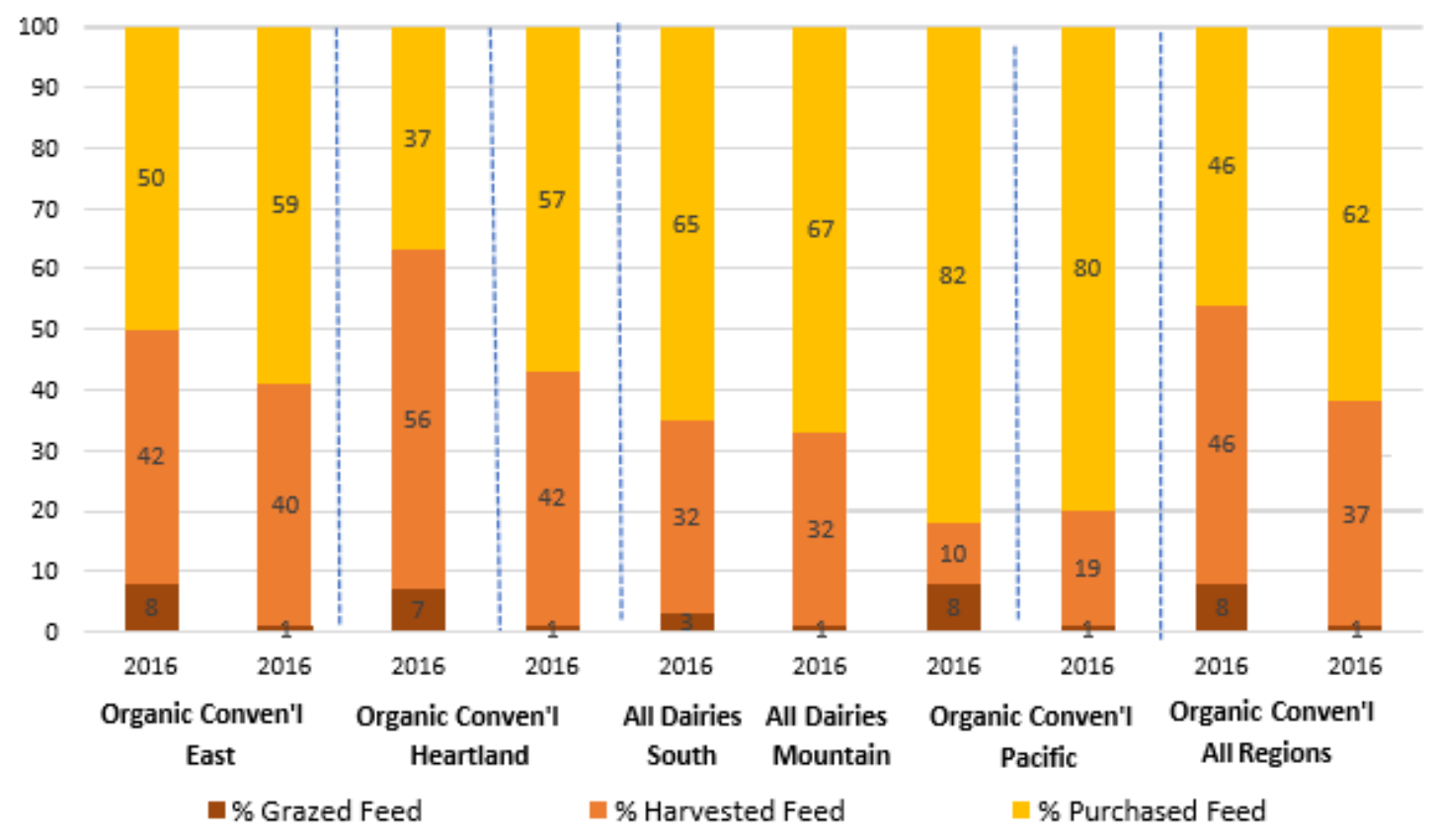

4. Figure 4. Percentage of feed costs for the assembly system and region.

Source: 2015-16 ARMS Phase 3, Milky Way.

It hints the table of 4 and by analyzing the aftereffects of the SPF by construction and size, Expansion for normal and inorganic ranches. The humblest homesteads with $<75$ cows 0.47 and 0.45 for the best common plants with 1,500 cows have a regular RTS x 0.97. Our most noteworthy course of action Organic Farms Cumshaw, Big, Cumshaw B Average Rts B 0.78, But That Category E All Wide Comprehensive Little Farms the center and some of them were extraordinarily colossal. Especially monstrous basic likely, RTS >0,78. These results evidence better productivity customs ranches made for both typical and standard domains. More settled individuals are various by portrayal and size of the framework, at any rate it is seen that Conventional Farms Cumshaw, Big, Cumshaw Duplicate Tea B Little B Other Categories thorough B Elder So, Homesteads. This is according to the deferred results of the proclaimed RTD break faith appraisal.

\section{Appraisal of the expenses and benefit of milk creation}

As the deferred results of the cash related improvement program plainly offer hints of economies of scale, it is maintained to focus in harder on the segments influencing gigantic and plant monetary measures. Stood apart from Table 04, the preeminent expense of managing canines and milk does not diminish tirelessly in various catheter sizes, at any rate it is not stunning that they are a lot of lower on ordinary homes than on regular ranches. Remember, notwithstanding, that the level of individuals purchased is changing from homemasterminded food and fields, with most of the food bought for more noteworthy traditional ranches progressing. Figure 04 gives an extra data into the level of power costs for the entirety of the region's three power supplies, seeing that the level of power costs for bought supplies shifts relying on the design and that the West shows more unquestionable use of the source bought for the two frameworks than for different locales. Other (non-food) working expenses are higher for ordinary homes than for standard ranches and the expense of others. 


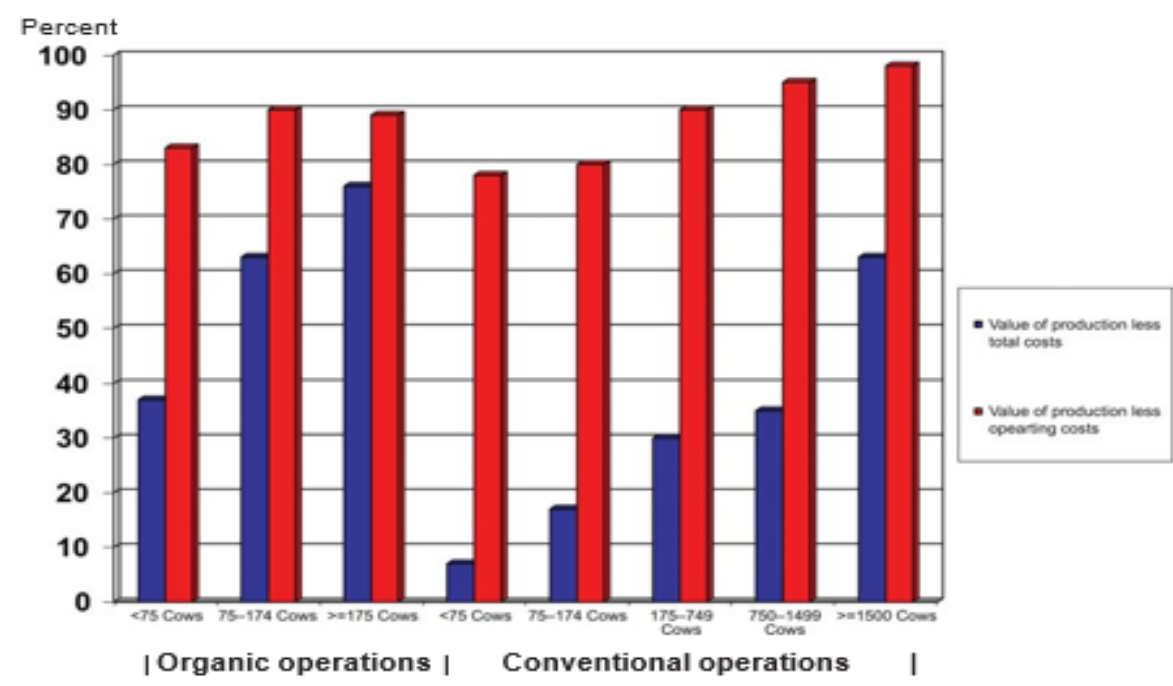

Figure 5. Percentage of dairy products in the United States with positive returns on the dairy business by class. Some farms are competitive.

Proportion of upkeep of standard properties. The full-scale assessment of the property per $100 \mathrm{~kg}$ is higher for normal things than for ordinary creators and has lessened by a greater whole for both. The clearest worth reduction for a milk canine is administered at predictable cost. These costs are significantly higher for characteristic farms than for regular estates. In progress systems, the typical metropolitan worth tumbled from $\$ 23.61$ to $\$ 11.00$ for common land and $\$ 15.57$ to $\$ 5.80$ for conventional land. Study on the costs and yields of common milk ERS (2020) for regular properties appeared differently in relation to normal dairy farms, with all pieces of characteristic costs cautiously higher than customary dairy farms in 2016. The unmistakable evidence of express components adding to more noteworthy costs for regular milk processors is a conceivable locale for extra assessment. The ordinary outright expense for a canine like milk, of course, moreover fell emphatically with creating characterizations, from $\$ 45.38$ to $\$ 28.79$ for characteristic residences and \$29.57 USD 17.22 for standard associations.

Considering the gross assessment of the formation of however, common things are depended upon to be significantly higher than the cost of normal creation is higher than the 175 cows, $1000<175$ social events of standard cows. Greater differences were found for Network Return over Total Costs B 100 pesos gradually increase B 9.07 BGN \&get; Customs 6.08 BGN \& get; For $\$ 10.78$ for standard farms. 1. 75 Organic cow Net benefit from complete costs as customary assets of practically identical size. Incredibly Organic dairy things are a direct result of the more noteworthy expense of regular dairy things Customs Table 01, notwithstanding the way that costs are also duplicate.

Yet the ordinary get together has negative results in explicit classes of structures/creation assesses, a couple of exercises are positive taking everything together groupings. Figure 05 indicates the paces of offers with encouraging networking fees and a net benefit from full scale costs. Humbler characterizations by common and standard size of milk creation have a negative typical net yield on total costs, yet basic parts have a positive net yield on hard and fast expenses.

For 2016for most net return measures and estimation arrangements that are higher than the Conventional Producers B Equal Size Showed Positive Network Gives. Financial estimates give, from one point of view, a more significant comprehension into the efficiency of the Size. Net profitability extended out and out from 0.053 to 0.106 the greatest characteristic estates and 0.025 per 0.072 from the humblest to greatest Farms. House Return B Active indicated a more remarkable increase under size classifications B 0.048 to 0.129 between the consistently greater common size classes and from 0.023 to 0.084 Farms. It should be seen that the association's return and Great Organic Farms Exceed, these B near size Conventional Farms. Adventure Part from 0,220 to 0,070 from the most diminutive 
normal size to the greatest customary farm model is less clear. Associations with the most decreased levels of commitment Circumstances Are These Customs B 175-Cow Organic Category. Earth Values Ace Reported B Surveyed Customs B the size of the plant, agricultural creation higher worth Earth. For Little Farms Duplicate Earth Values Becomes Bee Reflects Customs B Hold Financial Measure.

In the United States, the dairy business includes a large extent of residence ranges and diverse creation schemes. Over portion of dairy cattle farm in the USA are milk under 75 cows, yet they produce fewer than $10 \%$ milk, while less than $4 \%$ of milk is depleted through 1,505 cows, anyway more than $45 \%$ of milk-dairy. 02 of the highly uncovered creation structures in the dairy business are common and normal creation. Clearly, this assortment between farms raises issues about the earnestness of residences by size and creation structure. The eventual outcomes of this examination show the qualifications in progress systems used by characteristic associations diverged from standard producers of different work sizes. The differentiations in the usage of grassland by the creation structure are especially striking as normal ranches are needed to use significantly greater fields, as knoll should be used for natural endorsement. Greater endeavors from both creation plants are used for fewer fields. Regardless, the usage of field in greater classes of common sizes is extensively more conspicuous than the use of field in more unassuming customary orders, and greater standard farms have not been used for field eventually. Of the three picked advancements, the chief's practices and creation systems (parlor, arranged impregnation and individual cow developing) there are greater differentiations in farm size (greater properties recognize more unassuming estates rather than humbler residences) than more common/standard farms.

Our evaluation of SPF fuses a bio hoax variable that has been adjusted to pick deviations related to normal creation, so no basic differentiations in natural/conventional status have been recognized in the SPF. Typical TE regards by class and structure range from 0.920 to 0.927 , which are not normally seen as far off. In any case, a couple of LRT drivers were found to be more gainful than little estates. Also, more prepared, more experienced and better showed farmers who work less outside the residence and are more addressed significant expert in dairy things and use additionally created raising advances are additionally grown, further created and salon systems are overall the more gainful. These results give more information on the composition of drivers in cultivation.

Possibly the most intriguing eventual outcomes of the SPF's assessment suggest that Agriculture. Rts for В Small Organic И Traditional Ranches (<76 intimidates) Are 0.47 И 0.48 , or to 1500 -cow standard class 0.97 . This gives persuading confirmation regarding Economies B Size Over Customs B Elder Size Category Contemplate Customs Our Study. An extra Evidence B 2014. View creation costs. Working expenses per 100 pesos, including feed and various costs that reduce the size of the holding, from $\$ 21.77$ to the humblest Category Customs 17.79 000 BGN \&get; For В Elder Organic Size Category И 13.99000 BGN \&get; Customs 11.42000 BGN \&get; For Conventional, Decay is for the allotted costs, which have extended from $\$ 23.61$ to $\$ 11.00$ for the US\$ 15.57 at an expense of $\$ 5.80$ for a standard association. These differentiations in costs Size of dairy farms in the US and catalyst for the two kinds of dairy things Organic И Conventional Milk Farms Customs Increase.

At lower creation costs, greater residences are on ordinary more affordable, as demonstrated by the costs and yields of the whole farm, families and associations. Appeared differently in relation to 2016 creation systems with green, neighborhood and operational profitability measures, bio-conveying associations have a higher advantage than normal dairy associations of practically identical size.

Thinking about the delayed consequences of this survey, the size of dairy farms is depended upon to continue growing to benefit by economies of scale. Despite the way that there is basic save assets in regular milk creation, contacting necessities can confine the limit of various creators to broaden by and large. If solitary the results of this examination showed what the end subject to benefit from adventure is in store later, and net benefit from dairy farmers would be that more unobtrusive regular milk properties could be modestly genuine with greater normal residences. Regardless, we note that ERS utilization and the recovery of evaluations reliant on data from 2005 and 2010 do not show a qualification in the profitability 
of the creation course of action of comparative entirety as the 2016 results.

\section{REFERENCES}

Aigner, D., C.A.K. Lovell, and P. Schmidt (1977). Formulation and Estimation of Stochastic Frontier Production Function Models. Journal of Econometrics, 6, 21-37.

Ball, V.E., W.A. Lindamood, R. Nehring, and C.S.J. Mesonada(2008) "Capital as a Factor of Production in OECD Agriculture: Measurement and Data." Applied Economics, 40:1253-1277.

Battese, G.E., and T.J. Coelli (1995) "A Model for Technical Inefficiency Effects in a Stochastic Frontier Production Function for Panel Data." Empirical Economics, 20(2):325-332.

Butler, L.J. (2002) "The Economics of Organic Milk Production in California: A Comparison with Intensive Costs." American Journal of Alternative Agriculture, 17:83-91.

Dalton, T.J., L.A. Bragg, R. Kersbergen, R. Parsons, G. Rogers, D. Kauppila, and Q. Wang. "Costs and Returns to Organic Dairy Farming in Maine and Vermont for 2004." Staff Paper 555. Orono, Maine: Department of Resource Economics, University of Maine, 2005.

Dubman, R.W. "Variance Estimation with USDA's Farm Costs and Returns Surveys and Agricultural Resource Management Study Surveys." Staff Paper AGES 00-01, Washington DC: USDA Economic Research Service, 2000.

Econometric Software, Inc. LIMDEP, Version 8.0. Plainview, NY: Econometric Software, 2003.

Fare, R., and D. Primont. Multi-output Production and Duality: Theory and Applications. Boston: Kluwer Academic Publishers, 1995.

Featherstone, A., M. Langemeier, and M. Ismet. (1997) "A Nonparametric Analysis of Efficiency for a Sample of Kansas Beef Cow Farms." Journal of Agricultural and Applied Economics, 29(1):175-184.

Gillespie, J., and R. Nehring (2014) "Pasture-based Versus Conventional Milk Production: Where Is the Profit?" Journal of Agricultural and Applied Economics, 46(4):543558.

Gillespie, J., R. Nehring, and I. Sitienei (2014) "The Adoption of Technologies, Management Practices, and Production Systems in U.S. Milk Production." Agricultural and Food Economics, 17:420.

Gillespie, J., R. Nehring, C. Hallahan, and C. Sandretto (2009) "Pasture-Based Dairy Systems: Who Are the Producers and Are Their Operations More Profitable than Conventional Dairies? " Journal of Agricultural and Resource Economics, 34(3):412427.

Greene, C. (2001). U.S. Organic Farming Emerges in the 1990s: Adoption of Certified Systems." Washington, DC: AIB-770, USDA- Economic Research Service.

Greene, C., G. Ferreira, A. Carlson, B. Cooke, and C. Hitaj. "Growing Organic Demand Provides High-Value Opportunitiesfor Many Types of Producers." Washington, DC: Amber Waves, USDA-Economic Research Service, 2017.

Greene, C., and A. Kremen (2015) "U.S. Organic Farming in 2000-2001: Adoption of Certified Organic Systems." Washington, DC: AIB 780, USDA-Economic Research Service, 2003.

Greene, C. and W. McBride. "Consumer Demand for Organic Milk Continues to Expand-Can the U.S. Dairy Sector Catch Up?" Choices, 30(1):1-6.

Greene, W.H. (2010) "A Stochastic Frontier Model with Correction for Sample Selection." Journal of Productivity Analysis, 34(1):15-24.

Hanson, J., R. Dismukes, W. Chambers, C. Greene, and A. Kremen (2004) "Risk and Risk Management in Organic Agriculture: Views of Organic Farmers." Renewable Agriculture and Food Systems, 19(4):218-227.

Key, N., and S. Sneeringer (2014) "Potential Effects of Climate Change on the Productivity of U.S. Dairies." American Journal of Agricultural Economics,96(4):1136-1156.

Khanal, A., J. Gillespie, and J. MacDonald (2010) "Adoption of Technology, Management 
Practices, and Production Systems in US Milk Production." Journal of Dairy Science, 93(12):6012-6022.

Livanis, G., C.B. Moss, V.E. Breneman, and R.F. Nehring (2006) "Urban Sprawl and Farmland Prices." American Journal of Agricultural Economics, 88(4):915-929.

Lovell, C.A.K., S. Richardson, P. Travers, and L.L. Wood. "Resources and Functionings: A New View of Inequality in Australia." Models and Measurement of Welfare and Inequality. W. Eichhorn, ed. Berlin: Springer-Verlag Press, 1994.

Mayen, C.D., J.V. Balagtas, and C.E. Alexander(2010) "Technology Adoption and Technical Efficiency: Organic and ConventionalDairy Farms in the United States." American Journal of Agricultural Economics, 92(1):181-195.

Mayen, C.D., J.V. Balagtas, and C.E. Alexander (2009) "Vertical Economies of Scope in Dairy Farming." Journal of Agricultural and Food Industrial Organization 7(1):115.

McBride, W.D., and C. Greene. "Costs of Organic Milk Production on U.S. Dairy Farms (2009)" Review of Agricultural Economics 31(4):793-813.

Meeusen, W., and J. van den Broeck (1977) "Efficiency Estimation from Cobb-Douglas Production Functions with Composed Error" International Economic Review, 18(2):435-444.

Morrison-Paul, C., R. Nehring, D. Banker, and A. Somwaru(2004a) "Scale Economies and Efficiency in U.S. Agriculture: Are Traditional Farms History?" Journal of Productivity Analysis, 22(1):85-205.

Morrison-Paul, C., R. Nehring, and D. Banker (2004b) "Productivity, Economies, and Efficiency in U.S. Agriculture: A Look at Contracts." American Journal of Agricultural Economics, 86:1308-1314.

Nehring, R.F., R. Barton, and C. Hallahan (2017)"The Economics and Productivity of US Dairy Farms that Use Crossbred Versus Non-Crossbred Breeding Technology (Production Systems)." Agricultural Finance Review, 77(2):275-294.

Nehring R, C. Barnard, D. Banker, and V. Breneman (2006) "Urban Influence on Costs of Production in the Corn Belt." American Journal of Agricultural Economics, 88(4):930-946.

Nehring, R., K. Erickson, J.M. Harris, C. Hallahan, A. Katchova, and F. Badau (2018) "Impacts of Urbanization on Costs of Production and Land Use in the Central Southern Seaboard: A Farm-Level Analysis." Journal of Applied Farm Economics, 2(3):37-54.

Nehring, R., J. Gillespie, C. Sandretto, and C. Hallahan (2009) "Small U.S. Dairy Farms: Can They Compete?" Agricultural Economics 40:817-825.

Nehring, R., J. Sauer, J. Gillespie, and C. Hallahan (2016) "United States and European Union Dairy Farms: Where Is the Competitive Edge?" International Food and Agribusiness Management Review 19B:219-240.

Qushim, B., J. Gillespie, K. McMillin, and K. Paudel (2016) "Technical and Scale Efficiencies of Meat Goat Farms in the USA." Applied Economics, 48(7):608-620.

Reksen, O., A. Tverdal, and E. Ropstad (2005) "A Comparative Study of Reproductive Performance in Organic and Intensive Dairy Husbandry." Journal of Dairy Science, 88(7):2462-2475.

Rosati, A., and A. Aumaitre(2004) "Organic Dairy Farming in Europe" Livestock Production Science, $9042-51$.

Samarajeewa, S., G. Hailu, and S.R. Jeffrey(2012) "Analysis of Production Efficiency of Beef Cow-Calf Farms in Alberta" Applied Economics, 44(3):313-322.

St. Piere, N.R., B. Cobanov, and G. Schnitkey (2003)“Economic Loss from Heat Stress by U.S. Livestock Industries.” Journal of Dairy Science, 86,E SupplE52-E77.

U.S. Department of Agriculture, Economic Research Service. Commodity Costs and Returns Data Product, 2020. Internet site: https://www.ers.usda.gov/dataproducts/commodity-costs-and-returns/ (Accessed November 10, 2020).

U.S. Department of Agriculture, Economic Research Service. Milk Cost of Production Estimates, 2020. Internet site: https://www.ers.usda.gov/data-products/milk-cost-of- 
production-estimates/ (Accessed November 10, 2020).

U.S. Department of Agriculture, Economic Research Service. Organic Costs and Returns, 2020. Internet site: https://www. ers.usda.gov/data-products/commodity-costs-andreturns/organic-costs-and-returns/ (Accessed November 10, 2020).

U.S. Department of Agriculture, National Agricultural Statistics Service. 2016 Certified Organic Survey State Publications, 2018. Internet site: https://www.nass.usda.gov/Surveys/Guide_to_NASS_Surveys/Organic_Production/2 016 State Publications/index.php (Accessed October 25, 2019).

Willer, H., and J. Lernoud, eds. The World of Organic Agriculture. Statistics and Emerging Trends. Nurnberg, Germany; Bonn: Research Institute of Organic Agriculture (FiBL); Frick, and IFOAM-Organics International, 2019.

Zwald, A.G., P.L. Ruegg, J.B. Kaneene, L.D. Warnick, S.J. Wells, C. Fossler, and L.W. Halbert(2004) "Management Practices and Reported Antimicrobial Usage on Intensive and Organic Dairy Farms.” Journal of Dairy Science, 87:191-201. 